\title{
The Clinical and Electroencephalography Findings of Children with Pervasive Developmental Disorder
}

\author{
Yaygın Gelişimsel Bozukluğu Olan Çocuklarda Klinik ve Elektroensefalografi Bulguları
}

\author{
Semih Ayta1 ${ }^{1}$ Candan Gürses ${ }^{2}$, Zerrin Topçu Bilgen³ ${ }^{\text {, Ayşe Kılınçarslan³ }}$, Mefküre Eraksoy 4 \\ ${ }^{1}$ Haseki Training and Research Hospital, Clinic of Pediatrics, Child Neurology Unit, İstanbul, Turkey \\ 2istanbul University İstanbul Faculty of Medicine, Department of Neurology, Division of Clinical Neurophysiology, İstanbul, Turkey \\ 3istanbul University İstanbul Faculty of Medicine, Department of Child Psychiatry, İstanbul, Turkey \\ ${ }^{4}$ istanbul University İstanbul Faculty of Medicine, Department of Neurology, Division of Child Neurology, İstanbul, Turkey
}

\section{Summary}

Objective: The aim of this study was to document the findings in a case series of 43 patients diagnosed as having pervasive developmental disorder (PDD) and to show the relationship between these findings.

Materials and Methods: This study on children with autism was performed in child neurology and child psychiatry outpatient clinics. After neurologic and psychiatric detailed history and examinations, developmental tests were performed and electroencephalographies (EEGs) were recorded.

Results: In the systemic and neurologic examinations and investigations, findings of a specific disease that could cause autism was not detected. Among 34 of 43 patients, history of febrile seizures existed; eight patients (18.6\%) had epileptic seizures, $14(32.6 \%)$ had a period of autistic regression, and in the remaining 29 patients, the clinical picture had been present since birth. Among the 14 patients with regression, three had epileptic seizure histories. Twenty-two patients $(51.2 \%)$ showed epileptiform activity (EA) in their EEGs. In 14 patients with autistic regression, nine (64.6\%) had EA. Of the 29 patients with no history of regression, $13(44.8 \%)$ had EA. In the group of 22 patients with EA, six (27.3\%) had a history of seizures.

Conclusion: The diagnosis of PDD is made according to detailed history and examination. A certain disease that can be diagnosed co-exists in only a small percent of patients. For this reason, laboratory tests can not show much benefit. On the other hand, EEG recordings have great importance in the measurement of background activity of the brain and the existence of EA. During autistic regression, EEG recordings can have great benefits for patients with or without clinical seizures. It may be possible to distinguish between stereotypical movements, tics and epileptic seizures with EEG recordings, which will be repeated in time in these patients.

Keywords: Pervasive developmental disorder, autistic regression, electroencephalography, epileptiform activity

$\ddot{\mathbf{O} z}$

Amaç: Bu çalışma yaygın gelişimsel bozukluk (YGB) tanısı almış 43 olguda, klinik ve inceleme bulguları arasındaki ilişkilerin gösterilmesi amacını taşımaktadır. Gereç ve Yöntem: Çalışma Çocuk Nörolojisi ve Çocuk Psikiyatrisi Poliklinikleri'nde görülerek otizm tanısı almış çocuklarda gerçekleştirilmiştir. Olgular nörolojik ve psikiyatrik yönden ayrıntılı anamnez ve muayene ile değerlendirilmiş, gelişimsel testleri, uyku elektroensefalografileri (EEG), bazılarında kranyal manyetik rezonans görüntüleme incelemeleri yapılmıştır.

\footnotetext{
Address for Correspondence/Yazışma Adresi: Semih Ayta MD, Haseki Training and Research Hospital, Clinic of Pediatrics, Child Neurology Unit, İstanbul, Turkey Phone: +90 5326272463 E-mail: semayta@gmail.com

Received/Gelis Tarihi: 29.03.2016 Accepted/Kabul Tarihi: 20.04 .2016

${ }^{\circ}$ Copyright 2016 by Turkish Neurological Society Turkish Journal of Neurology published by Galenos Yayınevi.
} 
Bulgular: Araştırmaya alınan 43 olgunun yaşları 2,7-14,0 arasında, ortalama yaş 7,6 2, 2, erkek/kız oranı 3,3 olarak bulundu. Sistemik ve nörolojik muayeneler ve ileri tetkiklerde otizme neden olabilecek özgül hastalık bulgusu saptanmadı. Stereotipik hareketler $28(\% 65,2)$ olguda vard1; en sık gözlenenler el-kollarda kanat çırpma idi. Epileptik nöbetler sekiz $(\% 18,6)$ olguda, ateşli nöbet öyküsü dokuzunda $(\% 20,9)$ vardı. Olguların 14 ’ünün $(\% 32,6)$ otistik regresyondan geçtiği, 29 'unda $(\% 67,4)$ klinik tablonun baştan itibaren geri olduğu belirlendi. Regresyonu olan 14 olgunun üçünde, regresyon öyküsü olmayan 29 çocuğun beşinde nöbet öyküsü vardı. EEG incelemeleri $21(\% 48,8)$ çocukta normal sınırlarda bulundu. EEG'lerinde epileptiform aktivite (EA) olanların sayısı 22 (\%51,2) idi. Otistik regresyondan geçen 14 olgunun dokuzunda (\%64,3), regresyonu olmayan 29 olgunun 13 'ünde (\%44,8) EA saptandı. EA'sı olan 22 olgunun altısında $(\% 27,3)$ nöbet öyküsü vard1.

Sonuç: YGB tanısı ayrıntılı anamneze, kapsamlı psikiyatrik ve nörolojik muayeneye dayanır. Mental Bozuklukların Tanısal ve Sayımsal El Kitabı tanı kriterleri ile çeşitli ölçeklerden yararlanılır. Az sayıda olguda tanı konabilir bir hastalık tabloya eşlik etmekte, bu nedenle rutin ve ileri incelemelerin çok yararı ol(a)mamaktadır. EEG ise hem beynin temel biyoelektrik aktivitesinin değerlendirilmesi, hem de otizmde -epileptik nöbeti olmayan olgularda bile- sıklıkla görülebilen EA'ların saptanması ve takibi açısından değerlidir. Otistik regresyonlu olgulara, bu zaman diliminde yapılan ve uykuyu içeren EEG incelemelerinin, potansiyel yararı olabilecek antiepileptik ilaç tedavilerine kanıt sağlayabileceği akılda tutulmalıdır. Regresyon öyküsü olan/olmayan otistik olgularda süreç içinde yapılacak EEG tetkiklerinin stereotipik hareket ve tikler ile nöbetlerin ayırıcı tanısında katkı sağlayabileceği, ayrıca subklinik EA'ların saptayabileceği düşüncesindeyiz.

Anahtar Kelimeler: Yaygın gelişimsel bozukluk, otistik regresyon, elektroensefalografi, epileptiform aktivite

\section{Introduction}

Autism is one of the severe clinical pictures of early childhood, and the main symptoms are qualitative impairments in social relationships, and verbal and nonverbal communication, and limitations in interests and activities (1). Autism spectrum disorders is also used nowadays instead of PDD $(1,2)$.

Some non-specific problems are defined in the prenatal, perinatal and postnatal medical history of patients with autism (3). There are many diseases that cause autism or autism symptoms (4). Evidence for a neurobiologic basis of autism has been detected by investigating neurologic diseases that cause autistic symptoms and by neuropathologic, neurochemical, and morphometric neuroimaging studies (5). The incidence of epileptic seizures and epileptiform activities on electroencephalography (EEG), even if there is no clinical seizure, is quite high in children with autism (6).

This study was performed in children who were suspected or diagnosed as having autism and admitted to our pediatric neurology and/or child and adolescent psychiatry outpatient clinic. All patients were evaluated with a detailed neurologic examination and psychiatric history. Developmental tests were applied and at least one sleep EEG recording was performed in all patients. Some of the patients also underwent cranial magnetic resonance (MR) imaging and congenital metabolic disease (CMD) screening tests. It was aimed to demonstrate the relationships between clinical and electroencephalographic findings and to evaluate these results in light of the literature.

\section{Materials and Methods}

Forty-three children who were diagnosed as having autism in the Pediatric Neurology Department or Child and Adolescent Psychiatry outpatient clinic at İstanbul University Faculty of Medicine Hospital, were included in this study. All patients underwent thorough neurologic and psychiatric examinations, Childhood Autism Rating Scale (CARS), Gesell developmental schedules or Denver 2 developmental screening test, and Autistic Behavior Checklist (ABC) forms were given to the parents.
Sleep EEG was recorded at least once and otolaryngology (ENT) examination was performed in all patients. Most of the patients underwent brainstem auditoryevoked potentials (BAEP) testing and routine blood and urine analysis. Some of the patients underwent CMD screening tests and cranial MR imaging.

\section{History and Clinical Features}

The following parameters were questioned in the detailed medical history: presence of any problems in the pre-, peri-, and postnatal period; motor development stages; early symptoms that may be associated with autism; age of first words; presence and types of epileptic and/or febrile seizures; and use of antiepileptic drugs (AEDs). Parental consanguinity, and family history of late speech, speech disorders, hearing problems, and febrile or epileptic seizures were also investigated.

In the psychiatric examination, patients were evaluated in terms of cognitive and behavioral assessments, including social relations, verbal and nonverbal communication, interests and activities, and all patients were found to meet Diagnostic and Statistical Manual of Mental Disorders-4 diagnostic criteria for autistic disorders. The severity of autism was determined using CARS. This scale includes domains such as relationship to people, emotional response, adaptation to change, and a total score is obtained by summing the points of these domains. Total scores between 15-29 indicate that the individual is in the non-autistic range, scores between 30 and 36 indicate mild to moderate autism, and scores from 37 to 60 indicate severe autism.

The ABC formswere given to parents to complete and used as a screening test. The child's sensory, relating, language, social and self-help skills are scored with "yes" or "no" answers to sentence definitions (57 sentences such as "Whirls self for long periods of time", "Actively avoids eye contact"). Scores equal to or greater than 67 points support autism, whereas scores between 53 and 67 points represent moderate probability of classification as autism (7). CARS and ABC were translated into Turkish and validity/ reliability has been shown $(8,9)$.

Head circumference was measured on systemic examination, and patients were screened for deformity, dysmorphism, skin spots, and organomegaly. Although neurologic examinations in 
children with autism are difficult, the children in this study were observed for posture, balance, gait, the use of limbs and stereotyped movements, and we tried to evaluate them in terms of cranial nerves, tone, deep tendon reflex (DTR), and plantar reflex (PR).

The ear nose and throat (ENT) examination and BAEP testing were conducted at the Center for Children with Hearing Difficulties of the ENT department. Gesell developmental schedules was performed in most of the patients, Denver 2 developmental screening test was conducted in some, and the Standfort-Binet test in only two children by experienced psychologists. Language, motor, and personal-social development stages of patients were evaluated with development scheme/ testing. These tests were also translated into Turkish and validity/ reliability has been shown $(10,11,12)$. Some of the patients underwent routine blood/urine analysis and CMD screening tests (e.g., phenylketonuria, tyrosinemia, hyperglycinemia) were conducted at the child nutrition and metabolism department laboratories of the department of pediatrics. Neuroimaging without sedation is almost impossible in children with autism. Cranial MR investigations of some of the patients were performed at centers that provided this feasibility.

EEG recordings, including one or more sleep periods of at least 30 minutes and sometimes awake periods, were conducted inthe EEG laboratories of the Clinical Neurophysiology Department using a digital EEG device (Medelec DG Compact 32, Vickers Medical, Surrey, United Kingdom).

The typical settings for the EEG device were as follows: lowpass filter $0.5 \mathrm{~Hz}$, high-pass filter $70 \mathrm{~Hz}$, recording speed 30 $\mathrm{mm} / \mathrm{sec}$, and 16-22 EEG recording channels. Hyperventilation, intermittent photic stimulation and eye opening/closure was performed during awake EEG in compliant patients and sleep recordings were performed during spontaneous or oral chloral hydrate-induced sleep. All EEGs were visually examined in detail by experienced neurologists (S. A., C. G.) in terms of epileptic/ non-epileptic paroxysmal activities and baseline activity (BA). Focal/multifocal spikes, spike-slow waves, sharp-slow wave and generalized spike-slow waves were interpreted as epileptiform activities, whereas focal or generalized slow wave paroxysms as non-epileptiform activities. BA was considered "good" in the event of abundant vertex sharp waves, sleep spindles, and $\mathrm{K}$-complexes, which are phasic components of non-rapid eye movement sleep (NREM) [NREM, includes superficial (stage 1 and 2) and deep sleep (stage 3) outside rapid eye movement (REM) sleep]. BA was interpreted as adequate if these three components were sufficient or some were missing. BA was identified as inadequate if phasic components were not observed. Normal awake BA consists of $8-12 \mathrm{~Hz}$ alpha waves originating from parieto-occipital regions during wakeful relaxation with closed eyes. However, alpha waves in the pediatric age group are often physiologically confused with theta waves of 4-7 Hz frequencies. Considering the age, awake BA was classified as good, adequate, or inadequate.

\section{Ethics Committee Approval and Informed Consent}

The study were approved by the Haseki Training and Research Hospital of Ethics Committee Approval (protocol number: 300609-2). Parental informed consent form was filled out by all participants.

\section{Statistical Analysis}

SPSS version 11.5 was used for statistical analysis. Fisher's exact test was used when the expected values in any of the cells of a $2 \times 2$ contingency table were below 10 . If the value was more than 10 , Yates's chi-squared test was used. Pearson's chi-square analysis was used for contingency tables larger than $2 \times 2$ (mxn).

\section{Results}

\section{Demographic Factors}

The mean age of the patients was $7.6 \pm 2.8$ years (range, 2.714.0 years). The male/female ratio was found as $3.3[33$ boys $(76.7 \%)$ and ten girls $(23.3 \%)$. The mean ages at admission to the child and adolescent psychiatry and pediatric neurology department outpatient clinics were $3.9 \pm 2.1$ years (range, 1-11 years) and $4.9 \pm 2.4$ years (range, $1-12$ years), respectively.

\section{Medical History Features}

The number of patients with identified problems in the prenatal period was $18(41.9 \%)$. Problems associated with this period are shown in Table 1.

Twenty-five (58.1\%) births were vaginal and 18 (41.9\%) were caesarean births. Difficult birth; cord entanglement; meconium aspiration; cyanosis; late crying and oxygen requirement, which suggests the possibility of perinatal hypoxia, were present in 11 (25.6\%) patients.

Regarding motor development stages, informationcould be obtained from 30 families. Holding head was on time (2-3 months) in 29 children and delayed in one child. Unsupported sitting was on time (6-9 months) in 36 children and delayed in three children. Information could not be obtained in four children. Walking was on time (before 18 months) in $39(90.7 \%)$ children and delayed in the remaining four patients.

Some families could not provide information on eye contact, gurgling, and interest in toys during early infancy. Twentynine patients had eye contact during early infancy, seven had "less" or "none," and no information could be obtained for seven children. Twenty-three had gurgling and seven had none. No information could be obtained for 13 children. Twenty-three children had interest in toys in early-mid infancy and eight were disinterested. No information could be obtained for 12 children.

\begin{tabular}{|lcc|}
\hline \multicolumn{3}{l}{ Table 1. The problems in the prenatal period } \\
& Number & Ratio (\%) \\
$\begin{array}{l}\text { No feature } \\
\begin{array}{l}\text { The risk of abortion or preterm } \\
\text { labor }\end{array}\end{array}$ & 5 & 58.1 \\
$\begin{array}{l}\text { Problems related to pregnancy } \\
\text { (emesis, hyperemesis, } \\
\text { hypertension, edema, etc.) }\end{array}$ & 4 & 11.6 \\
$\begin{array}{l}\text { Infection or drug use during first } \\
\text { trimester }\end{array}$ & 3 & 9.3 \\
$\begin{array}{l}\text { Other (intense stress, infection or } \\
\text { drug use after first trimester) }\end{array}$ & 6 & 14.0 \\
Total & 43 & 100.0 \\
\hline
\end{tabular}


Twenty-nine children spoke their first words within normal periods, but speech was delayed in 11 . Three children were only able to say syllables. Of the 29 children who spoke their first words within normal periods, $25(86.2 \%)$ were boys and four $(13.8 \%)$ were girls. There were seven $(63.6 \%)$ boysand four $(36.4 \%)$ girlsin the group of children with delayed speech. Of the three patients who only spoke using syllables, two $(66.7 \%)$ were girls and one $(33.3 \%)$ was a boy. There was a large difference detected between the sexesin terms of time of first words, but it did not reach statistical significance $(\mathrm{p}>0.05)$.

Regarding language development in the finalclinical examination, 11 children were only able to pronounce syllables for requests, 20 were able to say words or sentences for requests, and 12 were using words/sentences for communication. Of the 11 children who were able to pronounce syllables only for requests, six $(54.5 \%)$ spoke their first words on time, two (18.2\%) were delayed, and three could not say any words. Of the 20 children who were able to say words or sentences for requests, $15(75 \%)$ spoke their first words on time, and 5 (25\%) were delayed. Eight $(66.7 \%)$ of the 12 children who were using words/sentences for communication spoke their first words on time, four $(33.3 \%)$ began speaking belatedly. The differences between the groups in terms of language development in the final clinical examination and the time of first words were statistically significant $(\mathrm{p}<0.05)$.

Febrile seizures was present in nine $(20.9 \%)$ children. A history of blank or "absent" stare, which is often observed in children with autism and sometimes difficult to differentiate from absence seizures, was present in eight $(18.6 \%)$ children and absent in 17 children. No information could be obtained for 18 children.

Epileptic seizures were identified in eight (18.6\%) patients and were not present in $35(81.4 \%)$ patients. The types of seizures were as follows: generalized tonic-clonic in 3 (one probably secondary generalized), generalized tonic in 2 and atonic seizures in 1 . Absence seizures were observed in one child during the clinical examinations. Seizures were under 1 year of age in two patients, between 1-7 years of age in two patients, and between 7-12 years of age in the other two patients. Seizures were continuing in one patient with secondary generalized seizures, and one patient with absence seizures. Seven $(87.5 \%)$ of eight patients with a history of seizures were boys and one $(12.5 \%)$ was a girl. There were 26 $(74.3 \%)$ boy sand nine $(25.7 \%)$ girls in the group of children without seizures. History of febrile seizures was present in two $(25 \%)$ of eight patients with epileptic seizures, and seven $(20 \%)$ of 35 children without epileptic seizures. A significant difference was not found between the groups in terms of epileptic seizures and presence/absence of febrile seizures $(\mathrm{p}>0.05)$.

Thirty-three $(76.7 \%)$ patients were not taking AEDs and 10 (23.3\%) were on AEDs. There was a history of seizures in four patients who were on AEDs. Although four of 33 patients who were not taking AEDs had a history of terminated seizures, seizures were not specified in 29 patients.

Detailed medical history and patient file information revealed that $14(32.6 \%)$ patients had autistic regression and $29(67.4 \%)$ patients had mental retardation from the beginning of the clinical picture.

Seizure history was present in three of 14 children with regression and five of 29 children without regression. There were no significant differences between the two groups in terms of regression and seizures ( $\mathrm{p}>0.05)$. Six $(42.9 \%)$ of 14 patients with a history of autistic regression and four (13.8\%) of 29 children with retardation from the beginning were on AEDs. Thus, a higher proportion of AED use was determined in patients with regression. The difference between groups in terms of presence of autistic regression and AED use was found to be statistically significant $(\mathrm{p}=0.055)$

\section{Family History}

There were relatives with delayed speech history in $13(30.2 \%)$ children, and relatives with language and speech disorders (stuttering, inability to pronounce some letters) accompanied by other problems such as hearing loss and mental retardation in 11 (25.6\%) patients. Six $(14.0 \%)$ patients had a family history of epilepsy and $10(23.3 \%)$ had a family history of febrile seizures. The other problems were as follows: neurologic problems such as mental retardation, "cerebral palsy" in the families of seven children, PDD in 2 families, and hyperactivity in 2 families. The number of families with parental consanguinity was $12(27.9 \%)$. There was no significant difference between the groups in terms of parental consanguinity and presence/absence of language and speech disorders in the family $(\mathrm{p}>0.05)$. Nine $(20.9 \%)$ of 43 patients in the study were the only children of the family. The number of siblings was one in $20(46.5 \%)$ families and two or more in $14(32.6 \%)$ families. Two patients were brothers/sisters. Apart from these, it was learned that brothers/sisters of five patients had medical problems (hyperactivity, mental retardation, speech disorder, migraines, nocturnal enuresis).

\section{Physical Examination Features}

Head circumference was within the normal range in 38 children and below the $3^{\text {rd }}$ percentile in one child. The patient with small head circumference was a girl, but she did not meet the criteria for Rett syndrometo be diagnosed. Head circumference could not be measured in four patients. Body weight and height were within normal limits in all patients. Systemic examination revealed large auricles in two $(4.7 \%)$ children and polydactyly and syndactyly in two children. There were hyperpigmented-spots in the skin of 10 (23.2\%) patients, but they did not meet the diagnostic criteria for neurocutaneus diseases.

Cranial nerve examinations were normal in 41 patients and convergent strabismus in neutral position was observed in two children. Muscle power and tone was normal in all patients. DTRs were normo-active in $37(86.1 \%)$ children, normo-to-hyperactive in five $(11.6 \%)$ patients and hyperactive in one $(2.3 \%)$ patient. PRs were bilaterally flexor in $36(83.7 \%)$ children, unilaterally flexor/extensor in four (9.3\%) patients, and bilaterally extensor in three $(7.0 \%)$ patients. Cerebellar tests were normal in 21 children, and could not be evaluated in 22 children. Gait was normal in 40 $(93.0 \%)$ children. Intoeing was present in two (4.7\%) children and one $(2.3 \%)$ child had scissors gait.

The number of patients with stereotyped movements was 28 (65.2\%). The distribution of these movements according to their types is shown in Table 2.

\section{Scales}

This study was a cross-sectional study that mostly involved patients under follow-up and recent patients. Sixteen $(37.2 \%)$ patients were classified as mild to moderate and $27(62.8 \%)$ 
patients as severe according to CARS, which was performed by child psychiatrists. ABC, a screening test completed by parents, revealed that $24(55.9 \%)$ children had definite autism, nine $(20.9 \%)$ children had probable autism, and five $(11.6 \%)$ children did not have autism. Five families did not complete the checklist. Thirteen $(81.2 \%)$ of 16 patients with mild-to-moderate autism according to CARS results were boys and three $(18.8 \%)$ were girls. Twenty $(74.1 \%)$ of 27 patients with severe autism were boys and seven $(25.9 \%)$ were girls. The differences between sexes in terms of the severity of autism were not significant $(\mathrm{p}>0.05)$.

There were stereotyped movements in $10(62.5 \%)$ of 16 patients with mild to moderate autism and $19(70.4 \%)$ of 27 patients with severe autism according to CARS. There was no significant difference between the groups in terms of the severity of autism and presence/absence of stereotyped movements ( $>0.05)$.

\section{Developmental Tests}

Gesell developmental schedules and Denver 2 developmental screening test revealed moderate language development in 14 patients, severely delayed language development in 23 patients, moderately delayed socialization in 18 patients, and severely delayed socialization in 19 patients. Thirty patients had moderately delayed motor skills and three had severely delayed motor skills. Twenty patients had moderately delayed ego adaptation and 12 had severely delayed ego adaptation. IQ was at the level of mild mental retardation (67 and 61) in two patients with StanfordBinet test results.

\section{Routine and Advanced Studies}

Routine blood-urine analyses were within normal limits in 23 children. Three had mild anemia and the tests could not be performed in 17 patients. CMD screening test was negative in 20 patients and could not be performed in 23 children. Routine ENT examination was normal in all patients. BAEP was performed in 34 patients and the results were normal.

Cranial MR imaging was normal in $22(51.1 \%)$ patients and within normal limits (such as terminal myelination areas) in five $(11.6 \%)$ patients. One patient had an infratentorialarachnoid cyst and one patient had small, non-specific white matter lesions. Cranial MR imaging could not be performed in 14 children.

EEG recordings were performed in all patients at least once (the number of patients with one EEG was 17; 43 patients had a total of 98 EEG recordings; most were sleep EEGs, but some included both wake and sleep states) during the follow-up period, and EEG

Table 2. The distribution of stereotyped movements

\begin{tabular}{|lcc|} 
& Number & Ratio (\%) \\
No & 15 & 34.8 \\
Hand and arm flapping & 12 & 27.9 \\
Body rocking, head nodding & 6 & 14.0 \\
$\begin{array}{l}\text { Bringing the hand or an object into } \\
\text { mouth }\end{array}$ & 1 & 2.3 \\
$\begin{array}{l}\text { Other (hitting head, whirling } \\
\text { around) }\end{array}$ & 3 & 7.0 \\
Multiple stereotypes & 6 & 14.0 \\
Total & 43 & 100.0 \\
\hline
\end{tabular}

recordings were normal or within normal limits in $21(48.8 \%)$ patients. Twenty-two $(51.2 \%)$ patients had epileptiform activity (EA) on EEGs and two of those patients also had non-epileptiform activities. BA was good in $25(58.8 \%)$ patients, adequate in 15 $(34.9 \%)$ patients, and inadequate in three $(7 \%)$ patients.

Of 22 patients with EA on EEG, nine had autistic regression and 13 did not. Five of 21 patients without EA had a history of regression. When viewed from another perspective, nine $(64.3 \%)$ of 14 patients with autistic regression and $13(44.8 \%)$ of 29 patients without history of regression had EA. There was no statistically significant difference between groups in terms of presence/absence of EA on EEG and presence of regression ( $p>0.05)$.

Seizure history was specified in six $(27.3 \%)$ of 22 patients with EA and $2(9.5 \%)$ of 21 children without EA. From another perspective, EA was present in $6(75 \%)$ of 8 patients with seizures and absent in two patients. Seizures were continuing in two of eight patients (Figure 1,2). Nineteen $(54.3 \%$ ) of 35 children without seizure history had no EA on EEG but it was present in the remaining $16(45.7 \%)$ patients (Figure 3). There was no statistically significant difference between the groups in terms of presence/absence of EA on EEG and presence/absence of seizure history ( $p>0.05)$. Of 22 patients with epileptiform EEG findings, EAs were focal in $20(90.9 \%)$ patients, focal and generalized in one $(4.55 \%)$ patient, and only generalized in one patient. The distributions of focal EAs according to hemispheres and regions are shown in Tables 3 and 4, respectively.

One of the 21 patients without EA was on AED treatment, and this patient did not have a history of epileptic seizure. AED was continued as it was thought to be more useful in behavioral aspects. Nine (40.9\%) of 22 patients with epileptiform EEG findings were on AED treatment. When viewed from another perspective, nine (90\%) of 10 patients on AEDs had EAs on EEG, four of whom had a seizure history. A statistically significant difference was found between the groups in terms of presence/absence of epileptiform EEG findings and AED use $(\mathrm{p}<0.05)$.

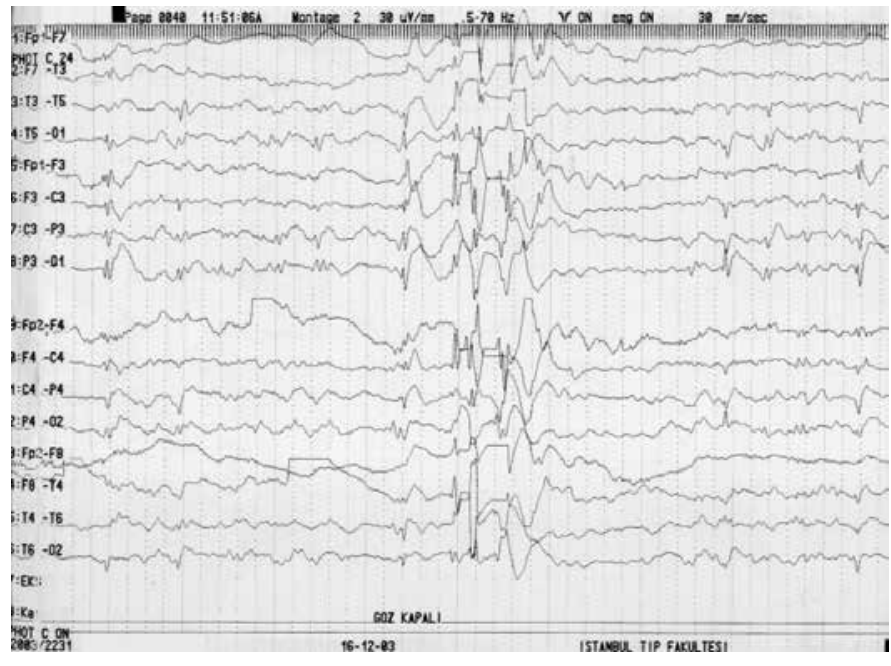

Figure 1. Irregular generalized epileptiform activities with eye closure during intermittent photic stimulation in awake status in a patient with absence seizures, and also focal epileptic focus 


\section{Discussion}

The etiology in PDDs is heterogeneous and there are known causes such as genetic and epileptic syndromes, neurocutaneus diseases, acquired processes, and metabolic disorders in only a small number of patients $(3,4,13)$. In the vast majority of patients, this disorder is idiopathic with an etiology of unknown cause (13).

No medical or biological test has yet been found for a definite diagnosis of autism (4). The first sign of autism usually noticed by parents is that their children "do not respond when they call his/ her name". All patients should undergo ENT examination, hearing tests, and BAEP examinations $(13,14,15)$. Epileptic seizures and/ or EAs on EEG are seen at high rates in patients with autism. The epilepsy rate in autism was found between $5-38.3 \%$ in studies in different age groups. The frequency of EA on EEG of children with autism and epilepsy was reported as $59-75 \%$, and this ratio is at the level of $8-15 \%$ in patients withoutepilepsy $(16,17)$. With this information, it is important to obtain a good seizure history and to perform awake-sleep EEG recordings in patients with PPD.

In this study, the male/female ratio was found as 3.3 in 43 patients with autism. In this relatively small group, consistent with the literature, autism was found more commonly in boys $(14,15)$.

Prenatal problemssuch as abortion/preterm labor and pregnancy problems, which are specified as frequently encountered in the medical histories of children with autism, were identified in $58.1 \%$ of patients. The findings suggestedthat the possibility of perinatal hypoxia was present in $25.6 \%$ of patients. The nonspecific pre-, peri-, and postnatal problems were not high in this study (3).

According to the families who could provide information about motor development stages, unsupported head and sitting were delayed in one and three children, respectively. The number

\begin{tabular}{|lcc|}
\hline $\begin{array}{l}\text { Table } 3 . \\
\text { according to the hemispheres }\end{array}$ & Number & Ratio (\%) \\
& 6 & 30.0 \\
Left & 7 & 35.0 \\
Right & 5 & 25.0 \\
Left and right & 2 & 10.0 \\
Midline & & \\
\hline
\end{tabular}

\begin{tabular}{|lcc|}
\hline $\begin{array}{l}\text { Table 4. The distribution of focal epileptiform activities } \\
\text { according to regions }\end{array}$ & Number & Ratio (\%) \\
Temporal, centro-temporal & 2 & 10.0 \\
Central, centro-parietal & 5 & 25.0 \\
$\begin{array}{l}\text { Frontal, fronto-temporal, fronto- } \\
\text { central }\end{array}$ & 7 & 35.0 \\
$\begin{array}{l}\text { Occipital, occipito-temporal, } \\
\text { occipito-parietal }\end{array}$ & 3 & 15.0 \\
Parietal & 1 & 5.0 \\
Multiple regions & 2 & 10.0 \\
\hline
\end{tabular}

of patients who started walking after 18 months of age was 4 . The indicating signs for autism spectrum disorders such as less/no eye contact, lack of gurgling, and lack of interest in toys were identified in $25 \%$ of patients. These findings suggest that informing families about clues for early diagnosis, paying attention to cognitive/ behavioral development issues besides motor development, and investigating children's home/family environment videos are of great importance (18).

The number of children who said their first words before 18 months of age was $29(67.4 \%)$ and those with delayed speech was $11(25.6 \%)$. The proportion of girls in these two groups was $13.8 \%$ and $36.4 \%$, respectively. Of the three patients who spoke only with syllables, two were female. There was a strong relationship between the time of first words and sex, but it did not reachsignificance. This situation suggests that language disorders in girls with autism might be more frequent; the general consensusis that autism is less common in females than males and

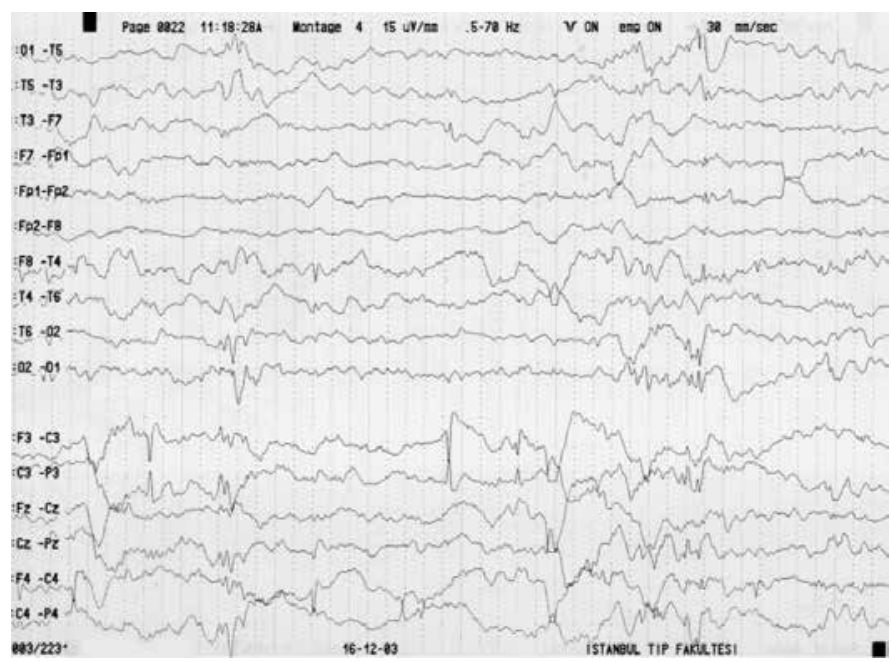

Figure 2. Epileptogenic foci (sharp waves and spikes) in the left and right temporal regions during sleep in the same patient

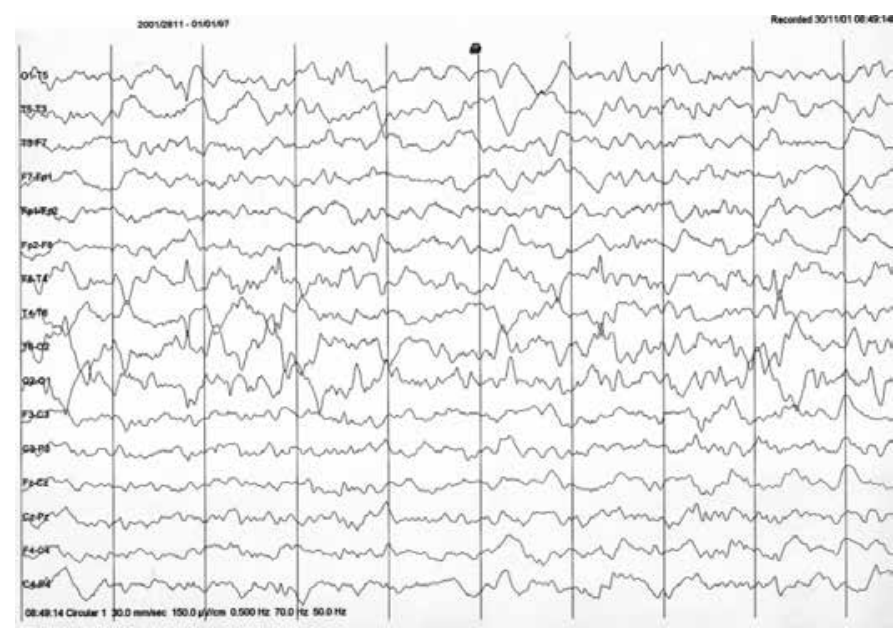

Figure 3. 1-3 Hz slow waves and sharp waves and spikes in the right temporal area on first sleep electroencephalography of a patient without seizure history 
that cognitive deficits are more severe in females, even if Rett syndrome is excluded $(15,19)$.

Regarding language development in the final clinical examination, $11(25.6 \%)$ children were able to pronounce only syllables for requests. Twenty $(46.5 \%)$ children were able to say words or sentences for requests and 12 (27.9\%) were using words/sentences for communication. Considering that $25 \%$ of the patients do not/cannot benefit from special training, it can be suggested that speech-language therapy along with special trainingmay provide significant benefit for communication and language problems, which are one of the most important signs of autism (20).

There were relatives with delayed speech history in $13(30.2 \%)$ children, and relatives with language and speech disorders accompanied by other problems in 11 (25.6\%) patients. These findings are consistent with the literature, which also found anincreased number of delays in speech and language disorders in families of children with autism (19). Fourteen percent of patients had a family history of epilepsy and $23.3 \%$ had a family history of febrile seizures. Two families had members with PDD and 2 families had members with hyperactivity. These findings suggest that the families of children diagnosed with autism had other developmental disorders besides those associated with language $(15,21)$. There is already a growing knowledge of the role of genetics in autism and studies are being conducted to determine different phenotypes $(4,22)$.

Cranial nerve examinations were normal in 41 patients and convergent strabismus in the neutral position was observed in two children. Muscle power and tone was normal in all patients. DTRs were normo-active in $37(86.1 \%)$ children and PRs were bilaterally flexor in $36(83.7 \%)$ children. Gait was normal in $40(93.0 \%)$ children and intoeing was present in two children. One child had scissors gait. Upper and lower DTRs were hyperactive in this patient whohad stayed in the neonatal incubator in the newborn period due to sepsis. Although a classic neurologic examination is very difficult in children with autism, it is possible to detect some signs of autism if a neurologic examination is combined with careful observation (19).

Stereotyped movements were observed in $28(65.2 \%)$ patients. The most commonly observed movements were hand and arm flapping (27.9\%), body rocking, and head nodding (14.0\%). Stereotypies are not specific to autism, but are known to present frequently in children with autism, especially in patients with more severe mental retardation $(3,13,23)$.

The children were evaluated using CARS by child psychiatrists, and the majority of patients were on special training. Sixteen $(37.2 \%)$ patients were classified as mild to moderate and 27 (62.8\%) patients as severe autism. ABC, which was completed by parents, revealed that $24(55.9 \%)$ children had definite autism, nine $(20.9 \%)$ children had probable autism and five $(11.6 \%)$ children did not have autism. The difference between $A B C$ and CARS results (five patients did not have autism according to $A B C$ ) was likely to be related to the evaluation of tha parents according to the previous status of their children, not according to their peers and/or also their inability to be objective.

The patients were detected to be moderately or severely delayed in language development and socializationin the Gesell developmental schedules and Denver 2 developmental screening test. IQ was at the level of mild mental retardation in two patients in the Stanford-Binet test results. The cognitive status of children with autism was determined using standardized IQ tests in most studies in the literature $(13,14,19)$. We believe that studies in children with autism in Turkey will be more valuable if standardized IQ tests are used.

ENT examinations in all patients and BAEP studies in 34 patients were normal. CMD screening tests performed in 20 patients were normal. Cranial MR imaging was normal/ within normal limits in 27 patients and there were non-specific pathologies in two patients. Routine and advanced examinations, except ENT examination, could not be completed in all patients due to economic problems. In addition, we did not insist on tests, because there were nofindings suggestive of a specific disease in children. On the other hand, pathologies that may be associated with autism (except $51.2 \%$ EA on EEGs) could not be detected in children with the performed tests. Although our study population was small, these findings suggest that only a small number of patients with autism have an underlying diagnosable disease, and that metabolic tests and neuroimaging are not informative in the absence of signs suggestive of an underlying specific disorder $(3,4,13)$.

Epileptic seizures were present in eight $(18.6 \%)$ patients. Of eight patients with seizure history, seven $(87.5 \%)$ were boysand one $(12.5 \%)$ was a girl. Of the 35 children without seizures, 26 $(74.3 \%)$ were boysand nine $(25.7 \%)$ were girls. History of febrile seizures was present in two $(25 \%)$ of eight patients with epileptic seizures and seven $(20 \%)$ of 35 children without epileptic seizures. There were no differences between groups in terms of epileptic seizures and presence/absence of febrile seizures, and as well as sex and epileptic seizures. The rate of epilepsy in children with autism (two peaks including the first 3 years of age and puberty) has been reported as $25-33 \%$ in the literature $(16,17,24)$.

All types of seizures can be seen in children with autism (3) and the most common types are complex partial, atypical absence, myoclonic, and tonic-clonic seizures (16). It is difficult to distinguish absence seizures from non-response when called and some motor seizures from stereotyped movements and tics (6). The risk factors for epilepsy in autism are age, presence of motor problems, the severity of cognitive deficits, and the extent of underlying brain lesions, if present $(3,6)$. Other accompanying disorders change the frequency of epilepsy in autism, but the rate of secondary autism with those disorders is very low (25). The $18.6 \%$ epilepsy rate in patients with autism in our study is consistent with the literature. Also, absence of a significant difference between groups with and without epileptic seizures in terms of male and female sex ratio is consistent with the opinion that these ratios are close to each other in the absence of severe mental or motor deficits.

In this study, $33(76.7 \%)$ patients were not taking AEDs and 10 (23.3\%) were on AEDs. There was a seizure history in four patients who were on AEDs. Although four of 33 patients who were not taking AEDs had a history of terminated seizures, seizures were not specified in 29 patients. The treatment of seizures in children with autism is not different from the treatment in children withepilepsy without autism (26); AED treatment can also have indirect positive effects besides seizure control in patients with both autism and epilepsy. The use of AEDs in patients with EA on EEG 
who have no history of seizure is a controversial issue $(3,13,27)$. In publications related to the cellular basis of autism, a significant portion of behaviors in children with autism has been reported to be associated with dysfunctions of structures such as the temporal lobe, hippocampus, amygdala, and neocortex (28). In addition, functional disorders in serotonergic, dopaminergic, gabaergic, and cholinergic systems also play a role $(27,29)$. These neuroanatomic and neurochemical abnormalities may be responsible for the high rates of epilepsy seen in children with autism. In addition, genetics has a major role in autism and seems to be an important variable in the association of autism with epilepsy (30).

Detailed medical history and patient file information revealed that $14(32.6 \%)$ patients had autistic regression and $29(67.4 \%)$ patients had mental retardation from the beginning of the clinical picture. History of seizures was present in three of 14 children with regression and five of 29 children without regression; however, there were no significant differences between the two groups in terms of regression and seizures. Six $(42.9 \%)$ of 14 patients with a history of autistic regression and four $(13.8 \%)$ of 29 children with retardation from the beginning were on AEDs. There was a large difference between groups in terms of presence of autistic regression and AED use and it was found to be statistically significant. Symptoms begin during infancy in the majority of children with autism; however, problems arise after normal or near-normal development in some patients. Autistic regression is characterized by loss of acquired speech, social and game skills before 2 years of age, and its prevalence is reported between $30 \%$ and $39 \%(17,31)$. The rate of children with identified regression in our study was $32.6 \%$, which is consistent with the literature. The causes of autistic regression are being discussed extensively. The importance of epileptiform EEG abnormalities in the pathophysiology of regression in autism has been reported in many studies, and the presence of epilepsy has been mentioned in a small number of studies $(32,33)$. In a study in children with speech regression who met the diagnostic criteria for autism spectrum disorder, the mean regression time was determined as 22.8 months. It was also found that patients who regressed before the age of three years were more likely to develop autistic behaviors (92\% in boys, $85 \%$ in girls), but had less epileptic seizures (14\%). However, more frequent seizures $(53 \%)$, but less autistic regression (69\% in boys, $33 \%$ in girls) were observed in patients with speech regression after the age of 3 years. As a result, it was emphasized that patients with speech regression at younger ages were more likely to have autistic regression, and older children were more likely to have clinical pictures associated with speech regression only (34).

EEG recordings in this study were performed at least once in all patients, and were normal or within normal limits in 21 $(48.8 \%)$ patients. Twenty-two $(51.2 \%)$ patients had EA on EEGs. Nine $(64.3 \%)$ of 14 patients with autistic regression and $13(44.8 \%)$ of 29 patients without history of regression had EA. Seizure history was specified in six $(27.3 \%)$ of 22 patients with EA. From another perspective, EA was present in $6(75 \%)$ of eight patients with seizures and seizures were continuing in two patients. Sixteen $(45.7 \%)$ of 35 children without seizure history had EAs on EEG. There was no statistically significant difference between groups in terms of presence/absence of EA on EEG and presence of regression, and presence/absence of EA on EEG and presence/absence of seizure history. The numeric results still showed significantly higher rates of EAs in patients with autistic regression and seizure history. The EA rate was detected as $46 \%$ on long-term video-EEG recording of patients with autism spectrum disorder with a history of regression, but without clinical seizures (33). We found an EA rate of $51.2 \%$ in our study. In a study in which no significant differences could be detected in patients with and without regression in terms of the prevalence of epilepsy and frequency of epileptiform EEG, the risk of EA was shown to increase two-fold in patients with regression when epileptic children with autism were removed from the analysis. In the same study, children with EAs in the centro-temporal (perisylvian) region were found as those with the highest rate of regression, but without seizures. It was also reported that the probability of regression in children with low cognitive functions in autism was higher, and that they had more epilepsy and epileptiform EEG prevalence rates (17).

Language disorders accompanied by epileptiform EEG abnormalities in children include Landau-Kleffner syndrome (LKS) [acquired epileptic aphasia (AEA)], developmental language disorders (developmental dysphasia), and continuous spikes and waves during slow-wave sleep (CSWS), as well as autism spectrum disorders. In these disorders, the relationship between epilepsy and problems in the language and/or other cognitive functions is unclear (35). One opinion is that epilepsy and dysfunctions in these fields are different aspects of a common disorder in the brain. However, some researchers argue that EAs directly lead to deteriorations in language and other cognitive areas (36). Verbal auditory agnosia (VAA) was reported asthe most common language disorder subtype associated with epilepsy and EA on EEG in autism and developmental language disorders $(16,17)$. VAA is also the most common type of language disorder in LKS $(17,37)$. According to studies that took AEA as a model, the developing brain is susceptible to epileptic seizures and EAs. In these studies, it was described that brain regions responsible for simple functions developed quickly and that brain regions associated with complex neuropsychologic functions underwent a long developmental process. It has been also stated that these functions are more damaged if developmental periods overlap epileptic processes. It was also considered that a specific learning disability could develop in children if other specific areas or more general cognitive functions were affected in addition to speech. It was thought that an acquired psychosis or an autistic disorder could emerge as the main problem if EA affected regions associated with behavior control. If EAs originate from non-functional or non-specific regions, the disorder cannot be noticed initially or deficiencymay be observed in the acquisition of these functions. An example of this is developmental language disorders and epilepsy association; the seizure rate in these children is higher than the normal population (36).

CSWS syndrome is characterized by epileptic seizures, neurocognitive regression, dyspraxia, attention deficit, hyperactivity, and autistic and/or psychotic behavior (37). The typical EEG findings are widespread spike-slow wave activity that are present on 3 or more EEG recordings and occupy more than $85 \%$ of NREM sleep (38). AEDs such as clobazam, valproic acid, and ethosuximide are used for seizures in LKS and CSWS. Corticosteroids and adrenocorticotropic hormone (corticotropin) are used mainly for language disorders in LKS and mental and 
behavioral disorders in CSWS syndrome, and intense EAs on EEGs, which are thought to be the main cause of these problems (39).

Although there is no clear evidence regarding the causal role of epileptiform EEG and epilepsy in autistic spectrum disorders, it was noted that the pathophysiology might be similar to the pathophysiology in LKS and CSWS syndrome, particularly in patients with regression history and EAs on EEGs $(36,40)$. Some researchers perform similar treatments to LKS in small children with only language regression or autistic regression, even in the absence of clinical seizures or EAs (41). The necessity for being that aggressive for treatment is very questionable, but data suggest that medical methods that suppress/terminate EAs in autistic regression patients with epileptiform EEGs would be useful. Thus, clinical recognition of patients while they are undergoing autistic regression and EEG recordings including sleep are important $(34,42)$. However, children aged less than two years who arestartingtowalk, a small number of children with regression but without clinical seizures draw the attention of their families and/or professionals, and only a small part of these children are followedup (3). The likelihood of detection of EAs in EEG is greaterin patients with seizures accompanied by autistic regression $(6,43)$.

\section{Conclusion}

Parents want to know whether there is a cause that leads to autism in children and ask the necessity of routine and/or further blood and urine analyses and neuroimaging. Families should be informed that different causes could cause autism and with the exception of BAEP and EEG, testsare informative in a very small number of children and therefore should not necessarily be performed in all children with autism. It should also be noted that these tests are planned in patients with detected signs in systemic and neurologic examinations, history of pre-, peri-, and postnatal damage, and/or regression, metabolic/genetic disease, and suspected seizures.

\section{Acknowledgments}

We would like to thank psychologists of child and adolescent psychiatry department for performing developmental tests; physicians and technicians of Center for Children with Hearing Difficulties for performing ENT examinations and BAEP tests; and Prof. Dr. Barış Korkmaz for his guidance and contribution in this work.

\section{Ethics}

Ethics Committee Approval: The study were approved by the Haseki Training and Research Hospital of Ethics Committee Approval (protocol number: 300609-2), Informed Consent: Parental informed consent form was filled out by all participants.

Peer-reviewed: Externally peer-reviewed.

\section{Authorship Contributions}

Surgical and Medical Practices: Semih Ayta, Candan Gürses, Zerrin Topçu Bilgen, Ayşe Kilınçarslan, Concept: Semih Ayta, Candan Gürses, Mefküre Eraksoy, Design: Semih Ayta, Candan Gürses, Mefküre Eraksoy, Data Collection or Processing: Semih Ayta, Candan Gürses, Zerrin Topçu Bilgen, Ayşe Kılınçarslan, Analysis or Interpretation: Semih Ayta, Candan Gürses, Mefküre Eraksoy, Literature Search: Semih Ayta, Candan Gürses, Writing: Semih Ayta.
Conflict of Interest: No conflict of interest was declared by the authors.

Financial Disclosure: The authors declared that this study received no financial support.

\section{References}

1. Washington DC APB. Mental Bozuklukların Tanısal ve Sayımsal Elkitabı. In: Köroğlu E. (ed). Hekimler Yayın Birliği, 1995:78-85.

2. In: Öztürk MO, Uluğ B (eds). ICD-10 Ruhsal ve Davranışsal Bozukluklar Sınıflandırması. Ankara: Türkiye Sinir ve Ruh Sağlı̆̆ı Derneği Yayını, 1993:238-245.

3. Rapin I. Autism. N Engl J Med 1997;337:97-104.

4. Muhle R, Trentacoste SV, Rapin I. The genetics of autism. Pediatrics 2004;113:e472-486.

5. Rumsey JM, Ernst M. Functional neuroimaging of autistic disorders. Ment Retard Dev Disabil Res Rev 2000;6:171-179.

6. Tuchman R, Rapin I. Epilepsy in autism. Lancet Neurol 2002;1:352-358.

7. Nordin V, Gillberg C. Autism spectrum disorders in children with physical or mental disability or both. II: Screening aspects. Dev Med Child Neurol 1996;38:314-324.

8. Gürkan A, Sütçü ST. Otizm davranış kontrol listesinin geçerlik ve güvenirliğ Nöropsikiyatri Toplantıları-II Otizm Sempozyumu. 2004.

9. Sucuoğlu B, Öktem F, Akkök F, Gökler B. Otistik çocukların değerlendirilmesinde kullanılan ölçeklere ilişkin bir çalışma. 3P Dergisi 1996;4:116-121.

10. Anlar B, Yalaz K. Denver II Gelişimsel Tarama Testi, Türk Çocuklarına Uyarlanması ve Standardizasyonu. Hacettepe Üniversitesi Tip Fakültesi Çocuk Nörolojisi Bölümü. 1996.

11. Cansever G. Klinik Psikolojide Değerlendirme Yöntemleri. Boğaziçi Üniversitesi, İdari Bilimler Fakültesi, İstanbul. 1982:230.

12. Aydoğmuş K, Gürkanlar K, Ezik Z. Zeka geriliği düzeyleri ile sosyoekonomik koşullar arasındaki ilişki konusunda bir çalışma. Nöropsikiyatri Arşivi 1977;14:39-44.

13. Rapin I. Autistic children: diagnosis and clinical features. Pediatrics 1991;87:751-760.

14. Tsai LY, Ghaziuddin M. Autistic Disorder. American Psychiatry Press, Washington, 2000;17:219-254.

15. Korkmaz B. Otizm ve Otistik Spektrum Bozuklukları. Pediatrik Davranı̧ Nörolojisi. İstanbul Üniversitesi Yayınları 2000;14:129-164.

16. Tuchman RF, Rapin I, Shinnar S. Autistic and dysphasic children. II: Epilepsy. Pediatrics 1991;88:1219-1225.

17. Tuchman RF, Rapin I. Regression in pervasive developmental disorders: seizures and epileptiform electroencephalogram correlates. Pediatrics 1997;99:560-566.

18. Baranek GT. Autism during infancy: a retrospective video analysis of sensorymotor and social behaviors at 9-12 months of age. J Autism Dev Disord 1999;29:213-224.

19. Tuchman RF, Rapin I, Shinnar S. Autistic and dysphasic children. I: Clinical characteristics. Pediatrics 1991;88:1211-1218.

20. Aman MG. Treatment planning for patients with autism spectrum disorders. J Clin Psychiatry 2005;66(Suppl)10:38-45.

21. Piven J, Palmer P. Psychiatric disorder and the broad autism phenotype: evidence from a family study of multiple-incidence autism families. Am J Psychiatry 1999;156:557-563.

22. Szatmari P, MacLean JE, Jones MB, Bryson SE, Zwaigenbaum L, Bartolucci G, Mahoney WJ, Tuff L. The familial aggregation of the lesser variant in biological and nonbiological relatives of PDD probands: a family history study. J Child Psychol Psychiatry 2000;41:579-586.

23. Bodfish JW, Symons FJ, Parker DE, Lewis MH. Varieties of repetitive behavior in autism: comparisons to mental retardation. J Autism Dev Disord 2000;30:237-243.

24. Tuchman R, Moshe SL, Rapin I. Convulsing toward the pathophysiology of autism. Brain Dev 2009;31:95-103.

25. Pavone P, Incorpora G, Fiumara A, Parano E, Trifiletti RR, Ruggieri M. Epilepsy is not a prominent feature of primary autism. Neuropediatrics 2004;35:207-210. 
26. Gillberg C. The treatment of epilepsy in autism. J Autism Dev Disord 1991;21:61-77.

27. Tuchman R. AEDs and psychotropic drugs in children with autism and epilepsy. Ment Retard Dev Disabil Res Rev 2004;10:135-138.

28. Brambilla P, Hardan A, di Nemi SU, Perez J, Soares JC, Barale F. Brain anatomy and development in autism: review of structural MRI studies. Brain Res Bull 2003;61:557-569.

29. Cook EH, Jr. Brief report: pathophysiology of autism: neurochemistry. J Autism Dev Disord 1996;26:221-225.

30. Tuchman R, Cuccaro M. Epilepsy and autism: neurodevelopmental perspective. Curr Neurol Neurosci Rep 2011;11:428-434.

31. Kobayashi R, Murata T. Setback phenomenon in autism and long-term prognosis. Acta Psychiatr Scand 1998;98:296-303.

32. Lewine JD, Andrews R, Chez M, Patil AA, Devinsky O, Smith M, Kanner A, Davis JT, Funke M, Jones G, Chong B, Provencal S, Weisend M, Lee RR, Orrison WW, Jr. Magnetoencephalographic patterns of epileptiform activity in children with regressive autism spectrum disorders. Pediatrics 1999;104:405-418.

33. Tuchman R, Jayakar P, Yaylali I, Villalobos R. Seizures and EEG findings in children with autism spectrum disorders. CNS Spectrums 1997;3:61-70.

34. Shinnar S, Rapin I, Arnold S, Tuchman RF, Shulman L, Ballaban-Gil K, Maw M, Deuel RK, Volkmar FR. Language regression in childhood. Pediatr Neurol 2001;24:183-189.

35. Pal DK. Epilepsy and neurodevelopmental disorders of language. Curr Opin Neurol 2011;24:126-131.
36. Deonna TW. Acquired epileptiform aphasia in children (Landau-Kleffner syndrome). J Clin Neurophysiol 1991;8:288-298.

37. Tassinari CA, Rubboli G, Volpi L, Catherine Billard, Michelle Bureau. Electrical status epilepticus in slow sleep (ESES or CSWS) including acquired epileptic aphasia (Landau-Kleffner syndrome). In: Roger J, Bureau M, Dravet Ch, Genton P, Tassinari CA, Wolf P (eds). Epileptic Syndromes in Infancy, Childhood and Adolescence, third edition John Libbey, Eastleigh, 2002;18:265-283.

38. Rossi PG, Parmeggiani A, Posar A, Scaduto MC, Chiodo S, Vatti G. LandauKleffner syndrome (LKS): long-term follow-up and links with electrical status epilepticus during sleep (ESES). Brain Dev 1999;21:90-98.

39. Sinclair DB, Snyder TJ. Corticosteroids for the treatment of Landau-kleffner syndrome and continuous spike-wave discharge during sleep. Pediatr Neurol 2005;32:300-306.

40. Mantovani JF. Autistic regression and Landau-Kleffner syndrome: progress or confusion? Dev Med Child Neurol 2000;42:349-353.

41. Neville BG, Harkness WF, Cross JH, Cass HC, Burch VC, Lees JA, Taylor DC. Surgical treatment of severe autistic regression in childhood epilepsy. Pediatr Neurol 1997;16:137-140.

42. Ayta S, Korkmaz B. Çocuklarda Dil-Konuşma Bozukluklarına Neden Olan Klinik Tablolar ve Epilepsi/EEG'deki Epileptik Aktiviteler Açısından Ortak Yönleri. Türkiye Klinikleri J Neurol-Special Topics 2012;5:14-20.

43. Hughes JR, Melyn M. EEG and seizures in autistic children and adolescents: further findings with therapeutic implications. Clin EEG Neurosci 2005;36:15-20. 